\title{
平面投影ステレオ視を用いた路肩検出
}

\author{
葛 西 達 哉*1 小野口 一 則*1 佐 藤 正 明*2 岩 瀬 耕 二*3
}

\section{Road Boundary Detection using Planar Projection Stereopsis}

\author{
Tatsuya Kasai*1, Kazunori Onoguchi*1 ${ }^{* 1}$ Masaaki Sato*2 and Kouji Iwase*3
}

\begin{abstract}
This paper presents a method to detect a road boundary using stereo images taken at on-vehicle stereo cameras. At first, an area whose height is different from a road plane is extracted by Planar Projection Stereopsis method. Next, boundary points between an obstacle and a road are detected and they are projected to a road plane. A road boundary is estimated in this projected images by the energy minimization method such as Snakes. The degree of a road boundary is calculated at each boundary point in a projected image. Road boundaries are estimated by searching a smooth line which passes on boundary poins whose the degree of a road boundary is high. Experimental results for real road scenes show the effectiveness of the proposed method.
\end{abstract}

Key Words: Stereo, Boundary Detection, Inverse Perspective Projection, Snakes, ITS, ASV

\section{1.はじめに}

近年, エレクトロニクス技術を活用し，自動車の事故防止や自 律走行を目指した様々な研究開発が高度道路交通システム（Intelligent Transport Systems; ITS）の一環として盛んに行わ れている $[1]$. これらのシステムに拈いて, 障害物検出や道路等 の走行路を認識する手法は必要不可欠であり, ミリ波レーダや レーザレーダなどを用いて障害物を検知する手法やカメラ画像 など光学センサを用いて障害物・道路平面を検知する手法など が提案されている，前者の手法は，発信した信号の反射により 応答時間を測定することで障害物との距離を得るが, 探索範囲 が狭いことや他センサとの干渉, 検知対象・環境により反射率が 変動するなどの問題点がある, 一方, 後者の手法は, 前者に比 ベて視野範囲が広く, 幅広い空間でより多くの情報を得ること ができる，また，視覚情報は走行レーンの検知，歩行者や対向 車などの障害物識別, 道路標識の認識など応用範囲が広く, 非 常に有効な手法であると言える。

ドライバー支援システムの機能として, 道路領域を検知し, 安全な走行路を推定する技術は重要であり, 画像処理により自 動車の走行路を推定する様々な手法が研究されている [2]〜 [11].

原稿受付 2009 年 8 月 31 日

$* 1$ 弘前大学大学院理工学研究科

$* 2$ 日立ソフトウェアエンジニアリング株式会社

*3マツダ株式会社

${ }^{* 1}$ Graduate School of Science and Technology, Hirosaki University

${ }^{* 2}$ Hitachi Software Engineering Corporation

${ }^{* 3}$ Mazda Motor Corporation

ロ 本論文は学術性で評価されました。
エッジの方向性や色情報, 消失点などを用いて道路上の白線を 認識・追跡する手法が一般的であるが，これらの手法は道路上に 白線が存在することを前提として扔り，駐車車両等によるオク ルージョンや白線が薄く途切れている場合の検出が難しい，特 に, 白線自体が道路上に存在しない場合は対応できない, 白線 のない道路に执いても走行路が推定できる手法を実現するため には, 道路面と高さが異なる画像中の路肩位置をステレオ視で 求める手法が有効である.

ステレオ視により獲得した三次元情報から雪の壁やガードレー ルなどを検出し, 走行路を推定する手法 [12] [13] が提案されて いるが，一定以上の高さを持つ点を道路面へ投票することで障 害物を検出するため, 高さの低い縁石などを路肩として検出す ることが難しい，ステレオ画像中で検出した消失点方向に向か う直線を道路面上に投影し, 投影画像上で直線同士の対応付け を行い, 歩道の段差, ガードレール, 駐車車両の側面などを検 出する手法 [14] も提案されているが, 直線部分の高さ情報しか 得られないため, 直線状の路肩が存在する場所でしか走行路が 推定できない.

本文では，縁石などの低い段差や直線形状を呈さない不規則 な路肩に対しても有効な路肩検出法を提案する. まず, 対応探索 が不要な平面投影ステレオ視により道路平面と高さが異なる障 害物領域を抽出する。 文献 [12] [13] の手法と異なり, 高さが道 路面に近い点も抽出するため, 縁石など低い段差の情報が欠落 することはない，次いで，道路面と障害物領域の境界において 高い值を示す路肩度を新たに定義し，障害物領域を道路面へ逆 投影した画像上で路肩度が高い点を通る垂直方向の線を Snakes を用いて検出する. Snakes の外部エネルギーとしてエッジ強度 
などを用いた白線検出手法 [15] はすでに提案されているが, 道 路面と障害物の境界の程度を示す路肩度を用いた例はなく, こ れにより道路面と障害物の境界位置へS Snakes の制御点を引き 寄せることができるため, 高さの違いを用いた走行路の推定が 容易になる。また, 路肩度の低い領域が一部現れても補間が可 能であり, 路肩の途切れやオクルージョンなどに頑健な路肩検 出が実現できる。

\section{2. 路肩候補画像の作成}

路肩候補画像は，平面投影ステレオ視により道路外領域を求 め, 道路領域間と障害物領域間の輝度相関から路肩候補点を検 出することで作成する.

\section{1 平面投影ステレオ視}

平面投影ステレオ視 [16] とは, 右画像中の全点が道路平面上 に存在すると仮定して左画像における見え方に変換した変換右 画像と, 実際の左画像との間の類似性を調べることで, 道路面 とは高さが異なる領域を検出する手法である。通常のステレオ 視と異なり, 対応点探索が不要なため, 計算コストを低く抑える ことができる. Fig. 1 を用いて，平面投影に基づくステレオ視 の概要を説明する，ステレオ視で用いる 2 台のカメラをそれぞ れ $C_{L}, C_{R}$ とする. まず, カメラ $C_{R}$ の画像 $I_{R}$ を道路平面上 へ逆投影する。次に, 逆投影された平面領域をカメラ $C_{L}$ で撮像 した際の画像 $I_{T}$ に変換する. $C_{R}$ のカメラ座標系は $O-X Y Z$, $C_{L}$ のカメラ座標系は $O^{\prime}-X^{\prime} Y^{\prime} Z^{\prime}$, 焦点距離は共に $F$ とす る. $I R$ 中の点 $(x, y)$ が道路平面上の点 $P$ へ逆投影され, $P$ が カメラ $C_{L}$ の画像面 $I_{L}$ 中の点 $\left(x^{\prime}, y^{\prime}\right)$ へ投影される場合を考え る. $C_{L}, C_{R}$ の光軸がほぼ平行であり, かつ道路のように $Z$ 軸 方向の計測範囲が $X$ 軸方向に比べて格段に広い場合, $(x, y)$ と $\left(x^{\prime}, y^{\prime}\right)$ の間には, 以下のアフィン変換の関係式 (1) が成り立 $\supset[17]$.

$$
\left[\begin{array}{l}
x^{\prime} \\
y^{\prime}
\end{array}\right]=\left[\begin{array}{ll}
1 & b \\
0 & 1
\end{array}\right]\left[\begin{array}{l}
x \\
y
\end{array}\right]+\left[\begin{array}{c}
-b V_{y} \\
0
\end{array}\right]
$$

ここで $b$ は定数, $V_{y}$ は消失点の $y$ 座標值であり, $I_{L}, I_{R}$ に おいて, 道路平面上の対応する画像座標 $\left(x^{\prime}, y^{\prime}\right),(x, y)$ の組を 式（1）に与え, 最小二乗法により求めることができる。このた め, カメラ $C_{L}, C_{R}$ を車両に設置した後, 道路平面上の特徵点 (横断歩道やセンターライン等の輪郭に含まれる角点等) を対話 的に対応付け, $b, V_{y}$ を算出する.

$I_{R}$ の各点 $(x, y)$ の変換後の画像座標 $\left(x^{\prime}, y^{\prime}\right)$ を式 (1) によ り求め, $I_{R}$ の変換画像 $I_{T}$ (Fig. $2(\mathrm{~b})$ ) を作成する. 道路平面 の特徵点を対応付けているため, 道路平面上の点は対応する道 路平面の座標と同じ位置に変換され, 先行車両など高さの異な る領域は, 異なる座標へ変換される.このため, $I_{L}$ と $I_{T}$ の間 の各画素の輝度の類似度を調べることにより, 道路平面と異な る高さを持つ領域が検出できる.

類似度は, 絞りや感度の違いなどから生じるステレオ画像間 の明度差を考慮し以下の正規化輝度差分とエッジ方向差分をそ れぞれ用いた。

\section{1 .1 正規化輝度差分}

正規化輝度差分による類似度 $\operatorname{Cor} N(x, y)$ は, 式 $(2)$ を用い て求める.

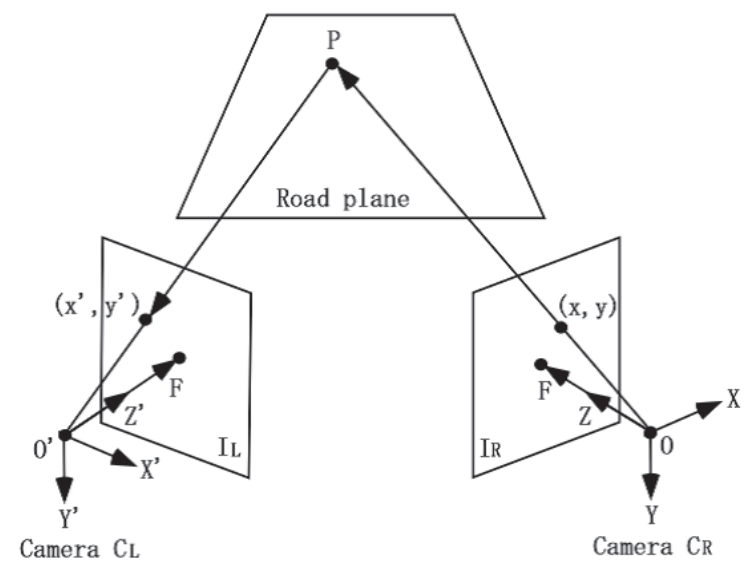

Fig. 1 Inverse perspective projection of stereo images

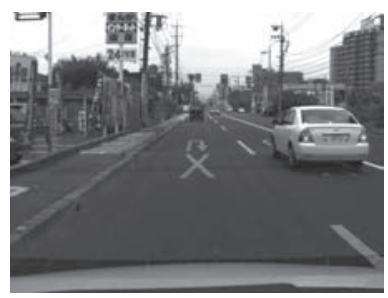

(a) Left image

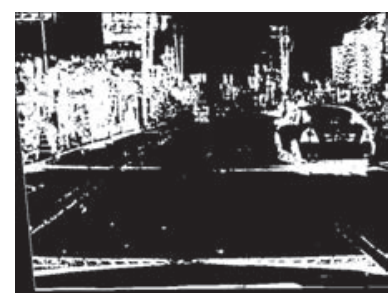

(c) Normalized intensity subtraction image

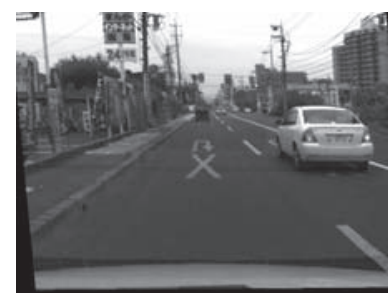

(b) Transformed image

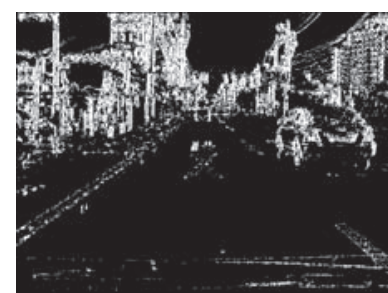

(d) Edge direction subtraction image
Fig. 2 Transformed image and subtraction images

$$
\begin{gathered}
\operatorname{Cor} N(x, y)=\frac{K_{n 1}}{\sqrt{K_{n 2} K_{n 3}}} \\
K_{n 1}=\sum_{d x=-l x}^{l x} \sum_{K_{n 2}=-l y}^{l y}\left|I_{T}(x+d x, y+d y)-I_{L}(x+d x, y+d y)\right| \\
K_{n 3}=\sum_{d x=-l x d x=-l y}^{l x} \sum_{d x=-l x d x=-l y}^{l y}\left|I_{T}^{2}(x+d x, y+d y)\right|
\end{gathered}
$$

$l x, l y$ は類似度を算出する際のウィンドウサイズである

$I_{L}, I_{T}$ の各点において $\operatorname{Cor} N(x, y)$ を求め, あらかじめ設定 していた䦨值 $T N$ 以下である画素を輝度值 0 , それ以外を 255 とする 2 值画像 $I_{b n}(x, y)$ を作成する (Fig. $2(\mathrm{c})$ ).

\section{1 .2 エッジ方向差分}

ソーベルオペレータにより $I_{L}, I_{T}$ のエッジ方向画像 $D_{L}, D_{T}$ を求め, 式 (6) によりエッジ方向差分による類似度 $\operatorname{Cor} D(x, y)$ を算出する。ソーベルオペレータにより得られた $x$ 方向の差分 
值を $d_{x}, y$ 方向の差分值を $d_{y}$ とすると, $\theta=\left|\arctan \left(d_{y} / d_{x}\right)\right|$ よりエッジの勾配方向の絶対值が $0^{\circ} \leq \theta<180^{\circ}$ の範囲で求ま る. エッジ方向画像 $D_{L}, D_{T}$ は, この $\theta$ を輝度值とした画像 である、

$$
\begin{gathered}
\operatorname{Cor} D(x, y)=\frac{K_{n 1}}{\sqrt{K_{n 2} K_{n 3}}} \\
K_{n 1}=\sum_{d x=-l x d x=-l y}^{l x} \sum_{T}^{l y}\left|D_{T}(x+d x, y+d y)-D_{L}(x+d x, y+d y)\right| \\
K_{n 2}=\sum_{d x=-l x d x=-l y}^{l x} \sum_{K_{n 3}}^{l y}\left|D_{T}^{2}(x+d x, y+d y)\right| \\
\sum_{d x=-l x}^{l x} \sum_{l y}^{l y}\left|D_{L}^{2}(x+d x, y+d y)\right|
\end{gathered}
$$

$l x, \quad l y$ は正規化輝度差分と同様に類似度を算出する際のウィン ドウサイズである. $D_{L}, D_{T}$ の各点において $\operatorname{Cor} D(x, y)$ を求 め, あらかじめ設定していた閯值以下である画素を輝度值 0 , そ れ以外を 255 とする 2 值画像 $I_{b d}(x, y)$ を作成する (Fig. $2(\mathrm{~d})$ ).

\subsection{3 ピッチング補正}

式（1）に含まれる $b, V_{y}$ を固定值として用いると, 車体の 摇れによる変換誤差が発生する. 舗装道路の場合, ロール方向 の摇れは小さいが, 段差などによるピッチングの影響は無視で きない.このため, 文献 [16]の手法を用いてピッチングの影響 を除去する。ピッチングが発生した場合, 左画像と変換右画像 の間に水平方向のズレが生じる。このズレは画像の縦軸（ $y$ 軸） に比例して大きくなるため, ズレ量 $e(y)$ は式 (10) に示される 1 次式で表される.

$$
e(y)=\beta y+\gamma
$$

左画像と変換右画像を走査線ごとに 1 画素ずつシフトさせなが ら相互相関係数を求め, 横軸にシフト量, 縦軸に画像の $Y$ 座標 軸をとる相関值画像（Fig. 3 (a)）を作成すると, 式（10）は輝 度の極大点を通る直線となる。このため, 相関值画像に Hough 変換を適用し, 投票数最大の直線 (Fig. $3(\mathrm{~b})$ ) を求めることで, ズレ量を表すパラメータ $\beta, \gamma$ を求める. ピッチングにより, 式 (1) の $x^{\prime}$ は, $e(y)$ だけズレるため, 式 (1) の右辺に式 (10) の右辺を加算し，ピッチング補正を施した変換式（11）を得る.

$$
\left[\begin{array}{l}
x^{\prime} \\
y^{\prime}
\end{array}\right]=\left[\begin{array}{cc}
1 & \beta+b \\
0 & 1
\end{array}\right]\left[\begin{array}{l}
x \\
y
\end{array}\right]+\left[\begin{array}{c}
\gamma-b V_{y} \\
0
\end{array}\right]
$$

Fig. $3(\mathrm{c})$ (d) にピッチング補正適用後に, それぞれの差分処理 を行った結果を示す.

\section{2 路肩候補画像の作成}

ピッチング補正後, 得られた正規化輝度差分画像 $I_{b n}$ とエッ ジ方向差分画像 $I_{b d}$ の論理和画像 $I_{o r}$ を求め, 道路外領域を得 る. Fig. 4 (a) にFig. 3 (c) および (d) の論理和より得られた道 路外領域を示す. 消失点より上の領域は処理に関係しないため, 除外している. 次に, 文献 [16]の手法を用い, 道路外領域と道 路領域の境界点（路肩候補点）を検出する. 処理の概要を以下に 示す. 注目点の上下に二つのウィンドウを設け，上部ウィンドウ

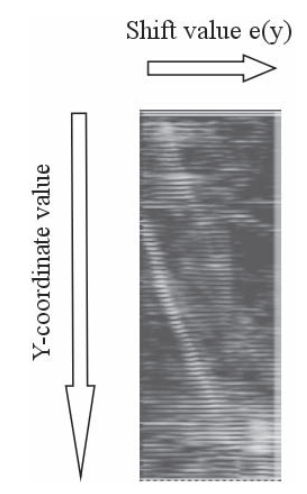

(a) Shift value

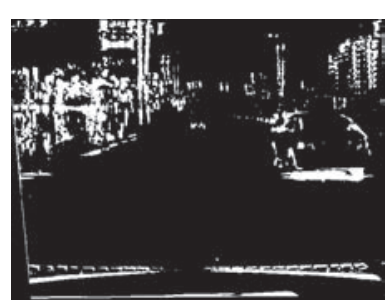

(c) Normalized intensity subtraction image

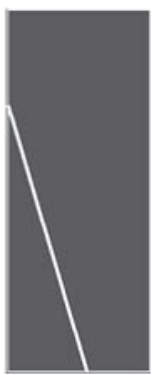

(b) Straight line with maximum voting value

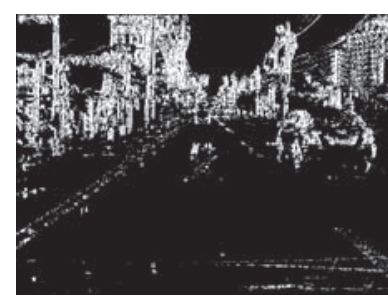

(d) Edge direction subtraction image
Fig. 3 Pitching correction

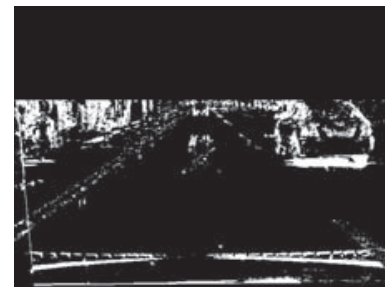

(a) OR operation image

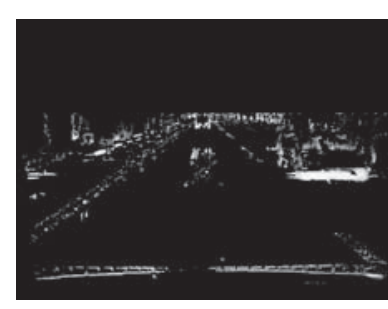

(b) Road boundary candidate image

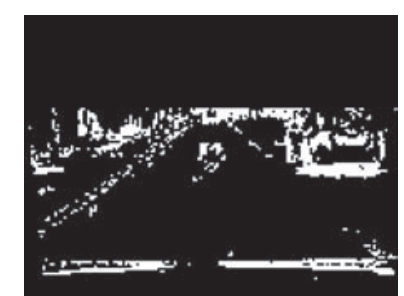

(c) Interpolated road boundary candidate image

Fig. 4 Area expect for a road and road boundary candidate image

では障害物領域間の相関として左画像 (Fig. 5 (Left image)) と右画像 (Fig. 5 (Right image) ) の輝度相関 $C_{T}$ を求め, 下 部ウィンドウでは道路領域間の相関として左画像 (Fig. 5 (Left image)）と変換右画像 (Fig. 5 (Transformed right image)) の輝度相関 $C_{B}$ を求める.

注目点が道路面上の点であると仮定すると, 式 (11) より左 右画像間の対応位置が算出できる。輝度相関は, 各ウィンドウ 内の輝度平均と分散で正規化した通常の相互相関係数を用いた. ウィンドウサイズは上部, 下部ともに $4 \times 25$ であり, この值は 

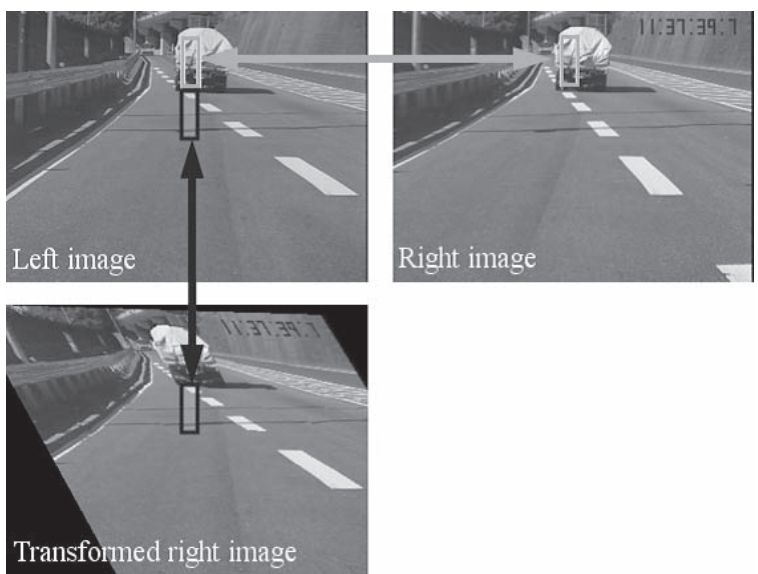

Fig. 5 Road boundary candidate detection

実験により定めた.

道路上の工作物や前方車両上などが注目点である場合, 障害 物領域間では左右画像間でのテクスチャはほぼ同じであるため 上部ウィンドウの輝度相関 $C_{T}$ は高くなるが, 道路領域間では 平面投影ステレオ視により異なる位置へ変換された画像との相 関となるため下部ウィンドウの輝度相関 $C_{B}$ は低くなる。一 方, 道路面上が注目点である場合, 道路領域間での変換位置は ほぼ同じであるため下部ウインドウの輝度相関 $C_{B}$ は高くなる が，障害物領域では左右画像間で道路面上の見え方が異なって いるため上部ウィンドウの輝度相関 $C_{T}$ は低くなる.よって, 注目点が障害物領域と道路領域の境界である場合に上下双方相 関值が高くなるため, $C_{T}$ と $C_{B}$ が一定以上大きな值を示す点 を検出し, 境界点（路肩候補点）として路肩候補画像を作成す る（Fig.4(b)）。また，コントラストが低い場合，路肩候補が 途切れ々々の点列として検出されるため, $4 \times 4$ の格子ブロック に分割し 2 点以上路肩候補点が含まれる格子ブロックを路肩候 補とする簡単な補完処理を行う (Fig. 4(c)).

左右カメラ間の基線長が大きい場合, 変換右画像の障害物領 域は左方向に大きく倒れ込む形で変換される（Fig. 5（Transformed right image)). この場合, $C_{B}$ は小さくなり, 障害物 上に路肩候補点が現れることはないが, Fig. 2 のように基線長 が $120[\mathrm{~mm}]$ と短い場合には, 障害物領域の倒れ込みの度合い が小さく, $C_{B}$ が十分小さくならない.このため, Fig. $4(\mathrm{~b}) に$ おいて, 道路面と障害物の境界以外の点も路肩候補点として検 出されている.

\section{3. 路 肩 検 出}

路肩候補点の途切れやオクルージョンに対応するため, 路肩 候補画像を道路面へ逆投影した画像を作成し，この逆投影路肩 候補画像上で路肩探索を行う。道路との段差部分で高い值を示 す路肩度を定義し, 高い路肩度を持つ点を通る垂直方向の路肩 線を Snakes [18] によるエネルギー最小化手法で求める.

\section{1 逆投影路肩候補画像の作成}

画像中の点 $(x, y)$ が道路面上の点 $(u, v)$ に逆投影される場 合, $(x, y)$ と $(u, v)$ の間には以下の関係式 (12)（13）が成り立 つ [19].

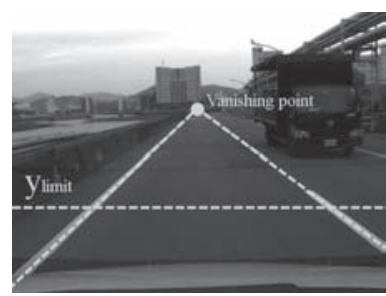

(a) Left image

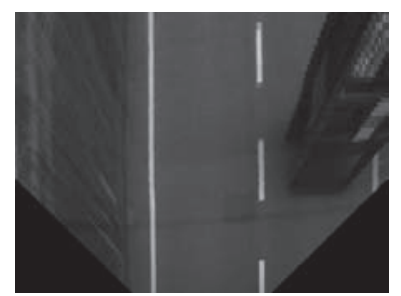

(b) Inverse perspective projection image

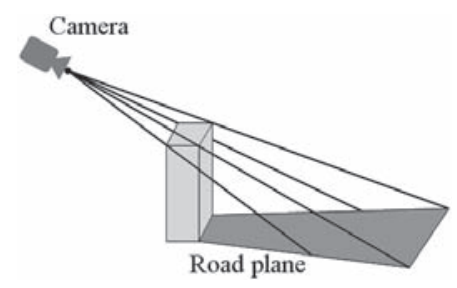

(c) Projected obstacle area

Fig. 6 Inverse perspective projection

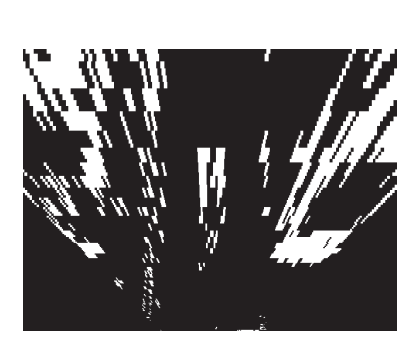

(a) Inverse perspective projection of the road boundary candidate image

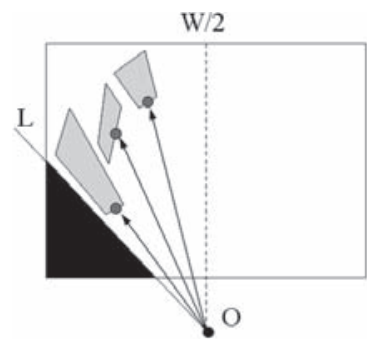

(b) Search origin
Fig. 7 Estimation of the search origin

$$
\begin{gathered}
u=\frac{R X}{y} x \\
u=\frac{R Y}{y}-\frac{R Y}{y_{\text {Limit }}}
\end{gathered}
$$

ここで, $R X$ は $X$ 方向の圧縮 (伸長) 率, $R Y$ は $Y$ 方向の 圧縮 (伸長) 率, $y_{\text {Limit }}$ は画像中の下限值である。また, 画像 中の座標值 $(x, y)$ は消失点位置を原点としている。建造物や車 両などは, Fig. 6 に示すように道路面との接点から後方へ放射 状に倒れ込んだ形で投影される. Fig. 7 (a) に逆投影路肩候補 画像の例を示す.

\section{2 探索原点の算出}

逆投影路肩候補画像において, 道路面と高さが異なる領域と 道路面との境界位置は, 放射状に外側へ路肩候補領域が連続し て現れる位置となる（Fig.7 (b) の矢印で示すような点). 歩道 など低い路肩の場合は，路肩候補領域が連続する幅は短くなる が, 路面テクスチャーなどの誤検出領域と比べるとこの幅は十 分大きくなる. 逆投影画像において放射状方向（角度）を決定 する探索原点 $O$ は, 逆投影画像における視野外領域の境界線 $L$ と画像中心線との交点から求まる (Fig. 7 (b)).

\section{3 路肩度の定義}

3.2 節で述べたように, 路肩は逆投影路肩画像において放射 


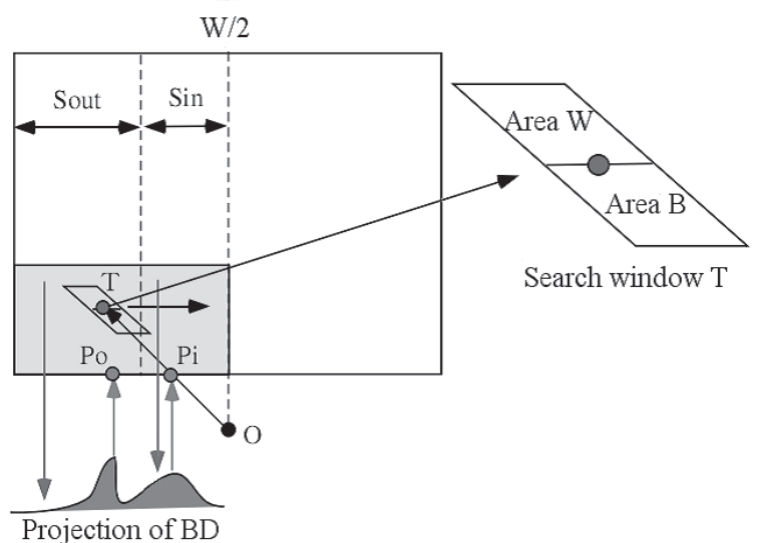

Fig. 8 Initial search position

状に外側へ路肩候補領域が連続して現れる位置となる。このた め, 式 (14) で示す路肩度 $B D$ を定義し, 路肩位置を求める. $B D$ は, Fig. 8 に示す平行四辺形の探索ウィンドウ $T$ 内の画 素を用いて求める. 探索ウインドウ $T$ はそのウィンドウ中心と 探索原点を結ぶ直線に平行な線と走査線方向の線から構成され る平行四角形であり，注目点であるウィンドウ中心の位置によ り異なる形状を持つ。

$$
B D=\frac{N_{W}+N_{B}}{N_{T}}
$$

$N_{W}$ は, Fig. 8 に示す $T$ の上部領域 $W$ 内に扔ける路肩候補 点（白点）の個数, $N_{B}$ は $\mathrm{T}$ の下部領域 $B$ 内に打名非路肩 候補点（黒点）の個数, $N_{T}$ は $T$ 内の総画素数である. $B D$ は, 路肩候補点が放射状後方に連続して出現する境界において高い 值を示す. Fig. 11 (b) に算出した路肩度 $B D$ を 0 255 の範囲 に正規化し，画像化した例を示す，歩道手前の縁石部分㧍よび 歩道奥の境界部分が高い路肩度を示している.

\section{4 路肩探索の初期位置検出}

逆投影路肩候補画像において, 路肩位置は路肩度 $B D$ が大き い点の連なりであり, 自車両の進行方向である垂直方向に存在 する可能性が高い. このため, 逆投影路肩候補画像上において 算出した路肩度 $B D$ を垂直方向に投影し, 投影值のピーク位置 (Fig. 8 の $P_{i}, P_{o}$ ) を通る垂直線を Snakesによる路肩位置探 索の初期位置とする，ただし，すべての点を垂直方向に投影す ると, カーブに扔いて初期位置がずれてしまうため, Fig. 9の 灰色矩形内の上うな，車両に近い領域に検出領域を限定する。

縁石などの外側に壁面などからなる路肩がさらに存在する可 能性があるため, 路肩探索の初期位置はエリア $S_{\text {in }}$ と $S_{\text {out }}$ の 二つの領域に执いて求める. 各領域内で投影值が最大となる位 置 $P_{i}$ と $P_{o}$ を求める. そして, $P_{i}, P_{o}$ の投影值があらかじめ 設定した閾值 $T H$ 以上である場合， $P_{i}, P_{o}$ を路肩探索の初期 位置とする，ただし， $P_{o}$ は $P_{i}$ と同じ路肩を対象とする可能性 があるため, $P_{i}$ から一定距離以上離れている場合にのみ探索の 初期位置とする.フレームごとに上述の手法で Snakes の初期 位置を決定する。

\subsection{Snakes による路肩探索}

Fig. 10 に示すように垂直方向に固定幅で分割し，各分割ラ

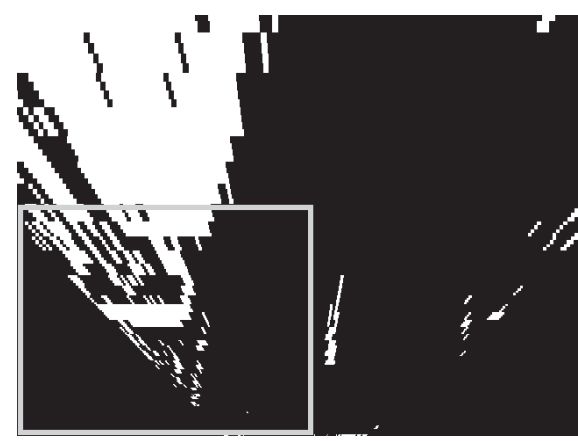

Fig. 9 Inverse perspective projection image at the curve

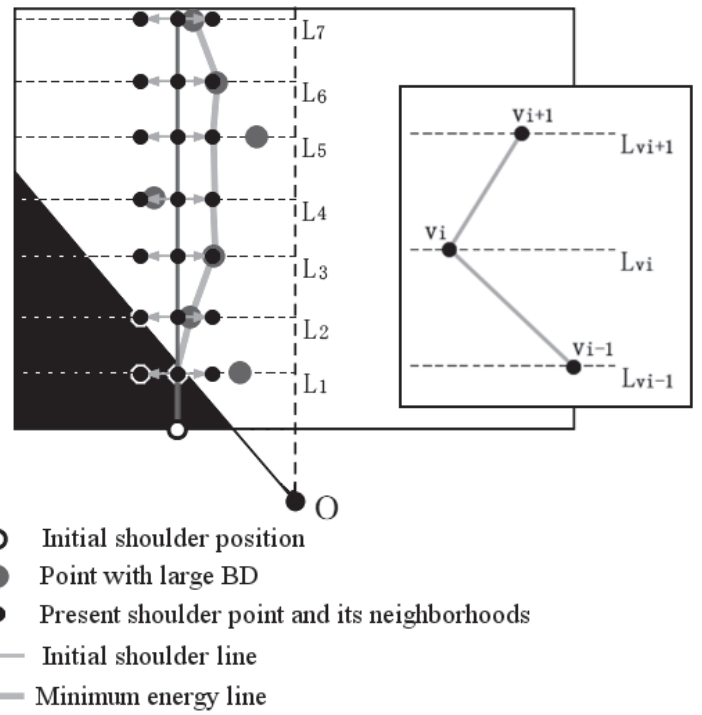

Fig. 10 Search for the road boundary

イン $L_{i}$ 上に Snakes の制御点を設定し，路肩位置の探索を行う. 各分割ラインに执いて, 路肩度 $B D$ の值が高く, かつ各分割ラ イン間ができるだけ滑らかに繋がる路肩位置を以下の Snakes の関数 $E$ を用いて求める [18].

$$
E=\alpha E_{\text {curv }}+\beta E_{\text {img }}
$$

ここで $\alpha, \beta$ は定数であり, 上下分割ラインの路肩候補点間の曲 率エネルギー $E_{\text {curv }}$ は

$$
E_{c u r v}=\left|v_{i+1}-2 v_{i}+v_{i-1}\right|^{2}
$$

である.ここで, $v_{i}$ は分割ライン上の路肩候補点の 1 点 $\left(x, y_{i}\right)$ である。 また, 路肩探索 $E_{\text {curv }}$ は, $E_{\text {curv }}$ の最大值, 最小值に より， $0.0 \sim 1.0$ (最小曲率〜最大曲率）に正規化する.

画像エネルギー $E_{i m g}$ は, 逆投影画像中の路肩度 $B D$ の強度 が高いほど小さい值を得るように正規化したものである.

$$
E_{i m g}=1-B D\left(v_{i}\right)
$$

全路肩候補点ごとにエネルギー $E$ を求め, 各分割ラインの路肩 位置の組み合わせを探索し， $E$ の総和を求める。この総和エネ ルギーが最小となる路肩候補の組み合わせが最適な路肩位置で あり, 路肩検出位置をこの位置に更新する。この路肩検出位置 


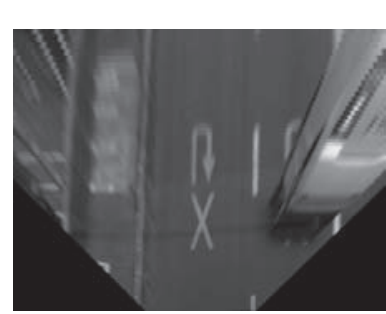

(a) Inverse perspective projection image

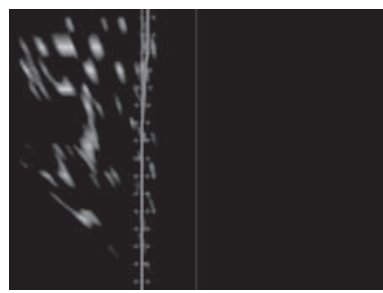

(c) The result of Snakes

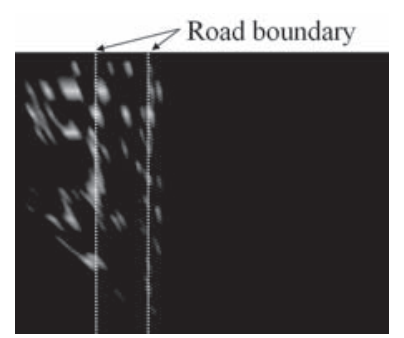

(b) The degree of a boundary

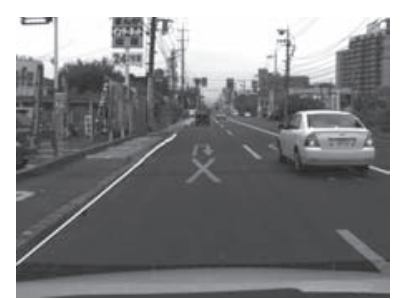

(d) The road boundary of a road

Fig. 11 Example of the road boundary detection

の更新を数回繰り返すことにより，適切な路肩位置が得られる。 各分割ライン上の全路肩候補点に対して組み合わせを探索す ることで正確な路肩位置を検出することができるが，計算量が 膨大になってしまう。このため, 前節で求めた路肩探索開始点 や更新前の路肩位置情報を用いて探索する路肩候補点を限定す る. Fig. 11 (c) に Snakes による路肩探索結果, Fig. 11 (d) に 検出された路肩線を原画像にオーバーレイした結果を示す.

\section{4. 実 験 結 果}

ルームミラー付近に設置した車載ステレオカメラ（Base Line $120[\mathrm{~mm}])$ から撮影されたステレオ画像に対して, 提案手法を 適用し，路肩を検出する実験を行った，撮影画像は $640 \times 480$, 30 [fps] の濃淡画像である. Pentium4 3.4 [GHz] の PC 上で, 撮影されたステレオ画像列を読み込み, 路肩検出を行っている. また, 路肩検出は左側路肩のみを対象に実行した。分割ライン 数 $i$ は 20 とし, 各ラインで探索する候補点は, 現在の路肩位置 の点, その左右近傍の点, 近傍で路肩度 $E_{i m g}$ が高い点の 4 点 に限定した（Fig. 10）。

Fig. 12〜17に，実験で用いた 6 シーンにおける路肩検出結 果を示す。シーン 1 (Fig. 12) は白線がなく歩道との境界が路肩 となっているシーンであり, 歩道端の縁石が路肩として正しく 検出されている. シーン 2 (Fig. 13) は白線も縁石もない市街 地の道路であり，上り坂の途中からパイプ状のガードレールが 現れるシーンである，民家と道路の境界およびガードレールの 根元を結ぶ線が路肩として検出されており, 縁石以外の不連続 な路肩に対しても本手法が有効であることを示している。シー ン 3（Fig. 14）は白線の外側に縁石が存在するシーンである. Fig. $14(\mathrm{e})$ (f) に示すように, 縁石は車両進入路において途切 れているが, 本手法は Snakes により路肩点を滑らかに繋ぐよ う路肩位置を推定するため, 縁石が途切れた位置においても路 肩位置が正しく検出されている. シーン 4 (Fig. 15) は踏切の

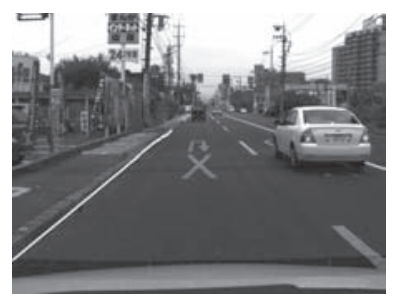

(a) Frame 0

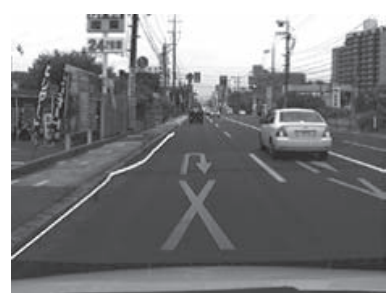

(c) Frame 12

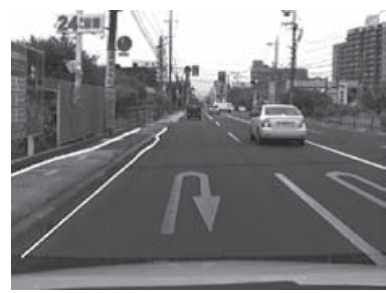

(e) Frame 23

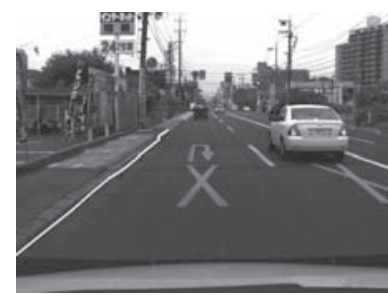

(b) Frame 8

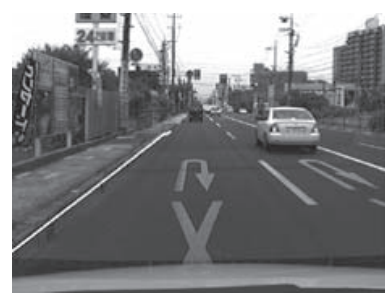

(d) Frame 17

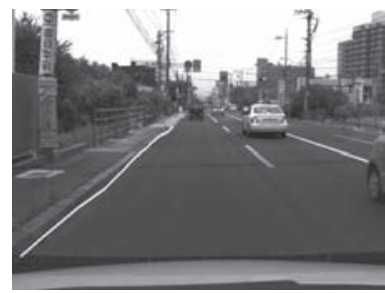

(f) Frame 39
Fig. 12 Result of the scene 1

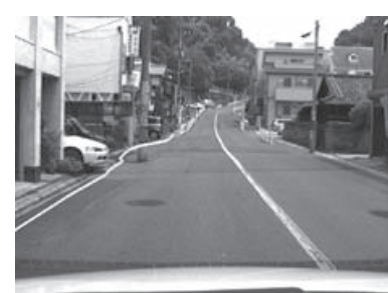

(a) Frame 2

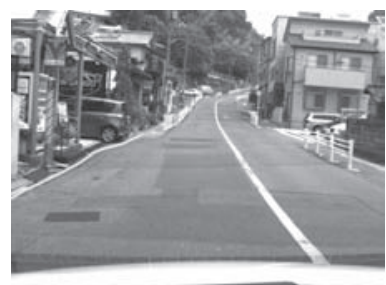

(c) Frame 25

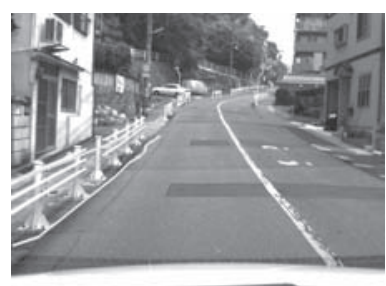

(e) Frame 76

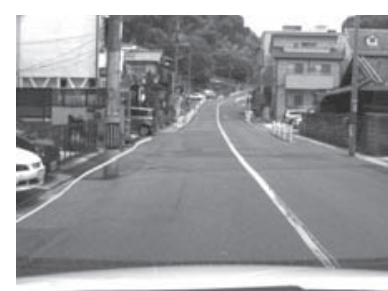

(b) Frame 11

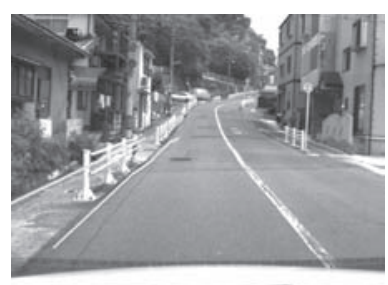

(d) Frame 51

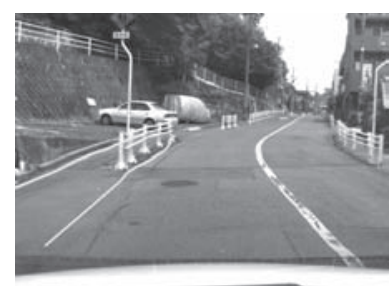

(f) Frame 115
Fig. 13 Result of the scene 2 


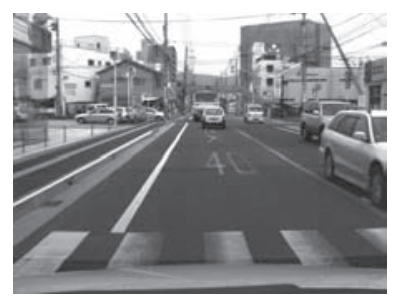

(a) Frame 2

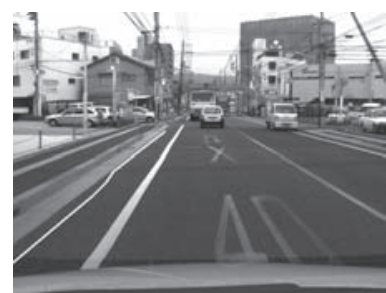

(c) Frame 15

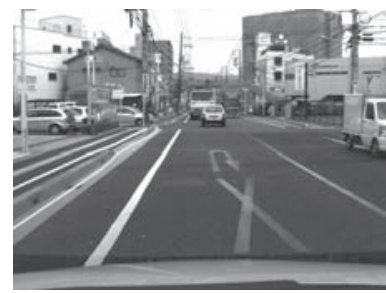

(e) Frame 29

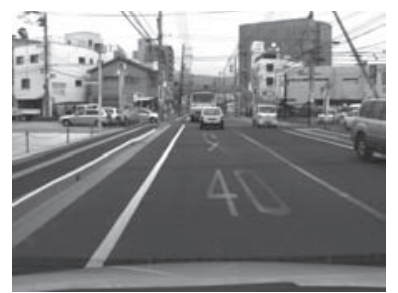

(b) Frame 9

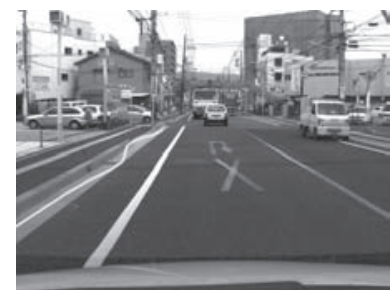

(d) Frame 23

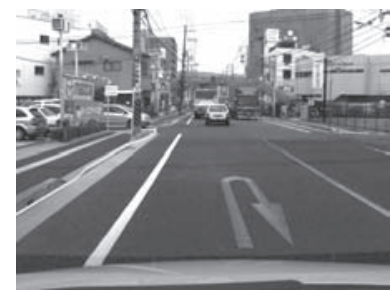

(f) Frame 39

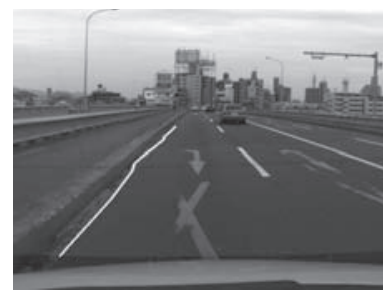

(a) Frame 1

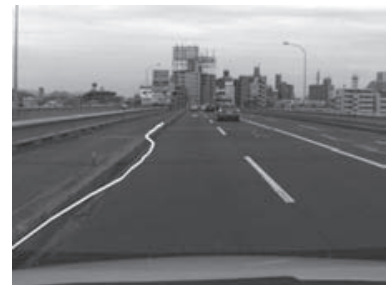

(c) Frame 21

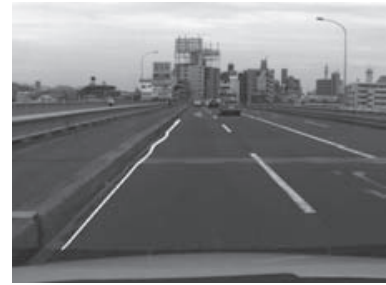

(e) Frame 39

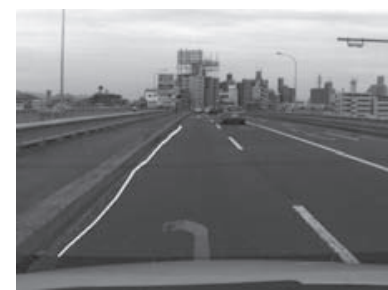

(b) Frame 11

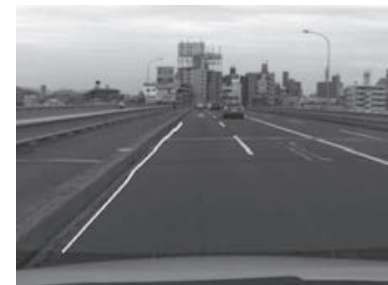

(d) Frame 31

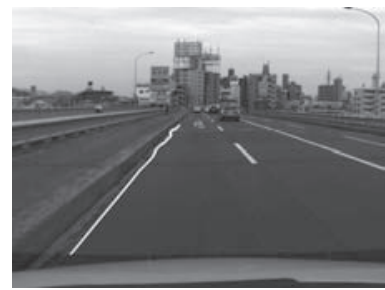

(f) Frame 49

Fig. 14 Result of the scene 3

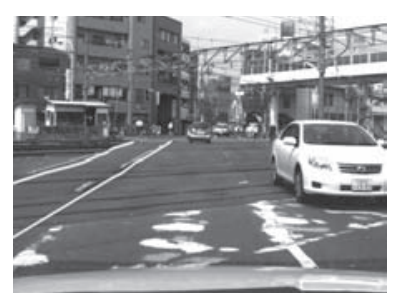

(a) Frame 1

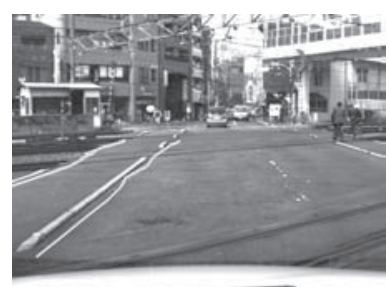

(c) Frame 46

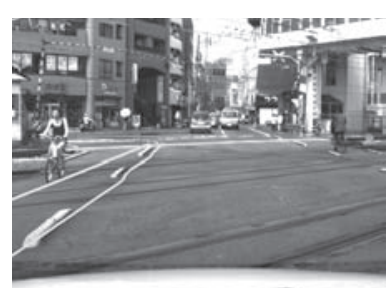

(e) Frame 85

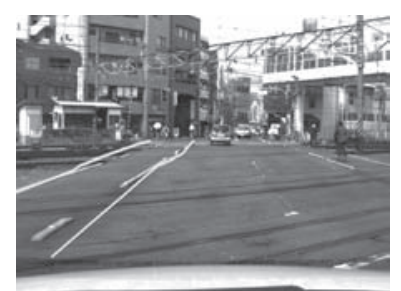

(b) Frame 24

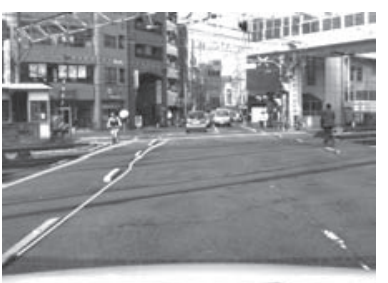

(d) Frame 68

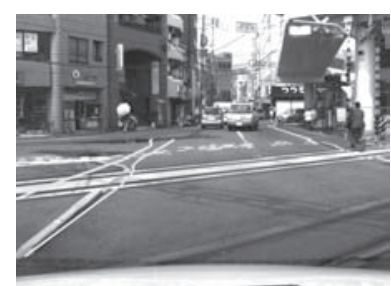

(f) Frame 123

Fig. 15 Result of the scene 4

Fig. 16 Result of the scene 5

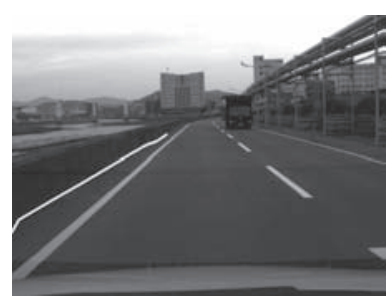

(a) Frame 1

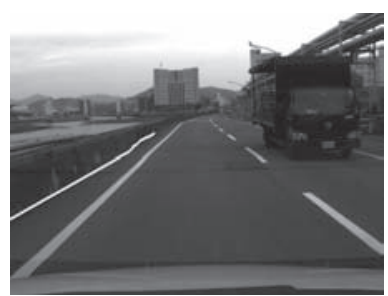

(c) Frame 20

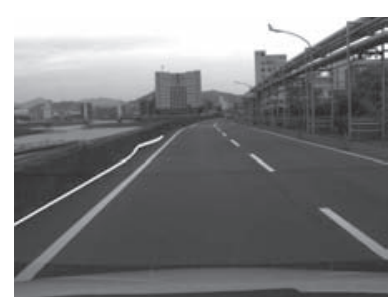

(e) Frame 34

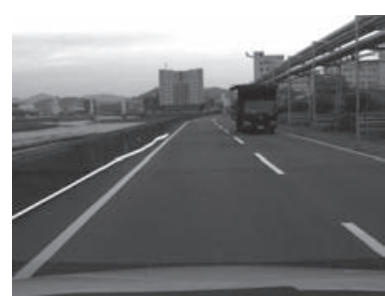

(b) Frame 10

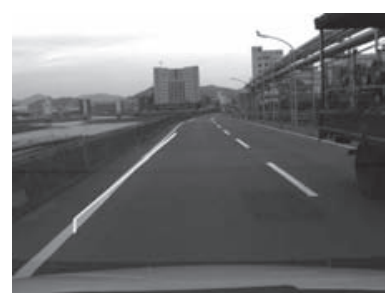

(d) Frame 27

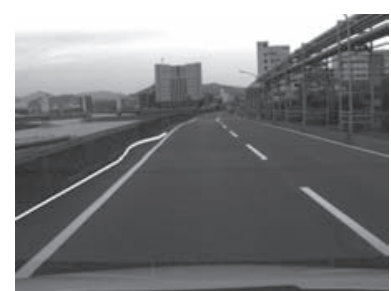

(f) Frame 45
Fig. 17 Result of the scene 6 
シーンであり, シーン 3 と同様に歩道との境界を示す縁石が一 部途切れているが, 途切れた部分も含めて路肩が検出されてい る. また，外側の路肩である歩道と砂利の敷かれた低地との間 の境界も検出されており, 道路に対して低くなっている段差も 路肩として検出できることが示されている. シーン 5 とシーン 6 はコントラストが低く路肩を示す縁石や壁面が見えづらいシー ンであるが, 本手法はS Snakes を用いて路肩位置を検出するた め, 路肩度の低い領域が一部存在しても, 路肩度の高い点を滑 らかに繋ぐことで全体を正しく検出することができる。

また, 路肩候補点を道路面へ逆投影し, 逆投影画像上で路肩 検出処理を行っているため, 遠方の路肩候補点が逆投影画像上 で拡大される。 この処理により, 路面のテクスチャーなどの誤 差領域も強調されるが，視差が小さい遠方の路肩情報が残るた め, Snakesにより手前の路肩から滑らかに路肩線を繋いでいけ ば遠方まで路肩線が正しく推定可能である。

平面投影ステレオ法は道路を平面と仮定しているが，車両近 辺の縦断勾配による誤差はピッチング補正（2.1.3 項）により無 視することができる，遠方の縦断勾配が車両近辺と異なる場合 には, 路面のテクスチャーを誤検出したり, 低い段差が検出しづ らいなどの問題が発生するが, 本手法は Snakesにより滑らかに 路肩候補点を繋いでいくため, 手前の路肩候補点が正しく求ま れば，遠方の路肩候補点に多少の誤差が含まれていても，シー ン 2（Fig. 13）に示すように路肩位置を正しく推定することが 可能である. また, 道路は中央付近が路局に比べて高い凸形状 を示すが，この影響で発生する平面投影ステレオ視の誤検出領 域は, 2.2 節で示した路肩候補点の検出処理により除去される. 横断勾配が路肩高よりも大きい場合には, 路肩が検出できない 可能性はあるが, シーン 1 (Fig. 12)，3 (Fig. 14)，4 (Fig. 15), 5 (Fig. 16) の結果に示されるように, 通常の道路の横断勾配は 問題になっていない.

シーン 1〜6に打いて, 検出された路肩位置の精度を式（18） を用いて評価した。

$$
P E=D W / R W
$$

逆投影画像上において, $D W$ は Snakesで検出された路肩位 置 (Fig. 11 (c)) と真の路肩位置との水平方向の差の絶対值（単 位: 画素) であり, $R W$ は走行車線の右端から真の路肩位置ま での道路幅（単位：画素）である。 また，すべての Snakes 制 御点に扔いて求めた $P E$ の平均值をフレームごとの路肩位置誤 差としている.

各シーンにおいて，5 フレームごとに複数枚の画像をサンプリ ングし, 求めた位置誤差の平均值と評価に用いた画像の枚数を

Table 1 に示す, 真の路肩位置は, 逆投影画像上において人間 が目視により, 高さが道路面と同じ部分の境界を指定した。全 6 シーンに扔ける路肩位置誤差の平均は $7.74 \%$ でり, 車線幅 が $3[\mathrm{~m}]$ 程度の道路の場合, 検出された路肩位置から約 $23[\mathrm{~cm}]$ 程度内側に走行路端を設定する必要がある。この誤差は, 車線 幅の広い道路や車幅の狭い車両の場合には問題ないと考えられ るが，大型車両などに適用する場合，位置精度をさらに高める 必要がある。

シーン 5 㧍よびシーン 6 に扔いて, 路肩位置の誤差が他シー
Table 1 Evaluation of position error

\begin{tabular}{|c|c|c|}
\hline Scene No. & Position Error(\%) & Evaluated(pics) \\
\hline 1 & 5.88 & 4 \\
2 & 5.90 & 57 \\
3 & 4.58 & 9 \\
4 & 7.19 & 16 \\
5 & 13.93 & 11 \\
6 & 8.98 & 11 \\
Average & 7.74 & \\
\hline
\end{tabular}

ンより大きくなっているが，これは路肩近辺のコントラストが 低いため, フレームによっては視差を求める上で必要なテクス チャーが十分得られず, 路肩近辺での路肩度が小さくなってし まったためと考えられる. 現在, Snakes の初期位置は, 3.4 節 で述べた手法をフレームごとに適用し, 求めているが, 前フレー ムに扔いて検出された路肩位置を, 次フレームの Snakes の初 期位置に用いれば，コントラストが低い路肩に対しても検出精 度は上げられると考えられる。

\section{5. ま と め}

ステレオ視で得た高さ情報から, 道路端である路肩を検知す る手法を提案した。本手法は, 平面投影ステレオ視を用いて路 肩候補画像を作成し, 逆投影路肩候補画像へ変換後, 探索原点 を用いて路肩度を算出する。 そして, Snakesにより高い路肩度 を示す路肩候補点を探索し, 路肩線の推定を行う. 様々な道路 シーンにおいて縁石, 壁面, ガードレールなどの路肩を検出す る実験を行い, 本手法の有効性を確認した。

今後の課題としては，以下の点が挙げられる.

·本手法は走行路として, ゆるやかなカーブや直線路を想定 しており, 曲率の大きいカーブや交差点などへの適用は難 しい，曲率の大きいカーブに対しては，地図情報などから 道路の曲率を入力し, Snakesの初期位置の設定に用いるな どの対応が必要と考える. また, 交差点など複雑な走行路 に対しては，交差点検出などの手法を別途開発していく必 要がある。

・本手法はフレームごとに Snakes の初期位置を検出するた め, カーブにおいて収束に時間がかかっている. 前フレー ムの路肩検出位置とヨーレートセンサなどから得られる車 両の回転情報を用いて次フレームの初期路肩位置を推定す れば，検出結果の安定性や処理速度の向上が図れると考え られる。

・本手法の目的は走行路を推定することであり, 障害物（車 両，歩行者など）の検出には対応していない. 既存のステレ オ視による障害物検出手法 [12] [13] [16] と組み合わせ, 障害 物が存在する場合の対処法を今後検討していく必要がある. ・晴天, 量天, 軽度の雨天に打いて収集した画像を用い, 本 手法の有効性を検証したが, 実用化のためには, 重度の雨 天など様々な天候に刘応できなければならない，本手法は, ステレオ視による高さ情報を用い, フレーム単位で処理を 行っているため, 明るさの変動にはある程度頑健である。 ま た, Snakesにより路肩線を求めているため, 路肩の一部が 視認できなくても, 視認性が高い手前の路肩検出結果から 
路肩線がある程度推定できると考えている，今後は，悪天 候時を含むより多くの画像を用いた評価実験によりこの点 を確認していく.

また, Snakes や類似度など各手法を見直し, 個々の手法を最 適化することにより，手法全体の高速化を目指していく.

\section{参 考 文 献}

[1] Z. Sun, G. Bebis and R. Miller: "On-Road Vehicle Detection: A Review," IEEE Transactions on Pattern Analysis and Machine Intellifence, vol.28, no.5, pp.694-711, 2006.

[2] V. Graefe: "Dynamic Vision Systems for Autonomous Mobile Robot," Proceedings of IROS '89, pp.12-23, 1989.

[3] M. Ohzora, T. Ozaki, S. Sasaki, M. Yoshida and Y. Hiratsuka: "Video-Rate Image Processing System for an Autonomous Personal Vehicle System," Proceedings of MVA '90, pp.389-392, 1990.

[4] 農宗千典：“高速道路走行画像からの消失点推定に基づく実時間白線 検出”, 電気学会論文誌 $(C)$, vol.113, no.2, pp.139-148, 1993.

[5] A. Kutami, Y. Maruya, H. Takahashi and A. Okuno: "Visual Navigation of Autonomous On-road Vehicle," Proceedings of IROS '90, pp.175-180, 1990.

[6] J. Lee, U. Yi and K. Baek: "A Cumulative Distribution Function of Edge Direction for Road-Lane Detection," IEICE Trans. Inf. \& Syst., vol.E84-D, no.9, pp.1206-1216, 2001.

[ 7 ] 二宮芳樹, 高橋新, 太田充彦: “高速パターン照合手法を利用したレー ン認識システム”, 電子情報通信学会論文誌 DII, vol.J86-D-II, no.5, pp.625-632, 2003.

[8] 山口直人, 田森信行, 塩見彰睦：“適応エッジ保存平滑化を用いた 白線検出手法”, 電子情報通信学会論文誌 D-II, vol.88-D-II, no.8, pp.1421-1431, 2005.

[9]田岡武司, 真鍋真, 上林学, 大西陽介, 福井正博：“自動車用白線認識
アルゴリズムの一実現”，情報処理学会研究報告，2006-SLDM-126, pp.63-68, 2006.

[10] W. Lu, H. Wang and Q. Wang: "A Synchronous Detection of the Boundary and Lane Marking for Intelligent Vehicles," Proceedings of 8th ACIS International Conference on Software Engineering, Artificial Intelligence, Networking and Parallel/Distributed Computing, vol.1, pp.741-745, 2007.

[11] H. Hattori and A. Maki: "Stereo without Depth Search and Metric Calibration," IEEE Computer Society Conference on Computer Vision and Pattern Recognition (CVPR '00), vol.1, p.1177, 2000

[12] 実吉敬二, 塙圭二, 喜瀬勝之： “三次元画像処理による道路形状と障 害物の認識”, 自動車技術, vol.46, no.4, pp.23-27, 1992.

[13] 関晃仁, 奥富正敏：“ステレオ動画像を用いた車両の前方環境認識”, 情報処理学会研究報告, 2007-CVIM-159, pp.1-16, 2007.

[14] 古川賢司, 岡田隆三, 谷口恭弘, 服部寛, 小野口一則：“ステレオ視 による走行レーンの検出”, 第 8 回画像センシングシンポジウム講演 論文集, pp.83-88, 2002.

[15] Y. Wang, E.K. Teoh and D. Shen: "Lane detection and tracking using B-Snake," Image and Vision Computing, vol.22, pp.269$280,2004$.

[16] 窪田進, 仲野剛, 岡本恭一：“車載ステレオ障害物検出システムのた めの実時間処理可能な全体最適化アルゴリズム”, 画像の認識・理解 シンポジウム (MIRU2006), pp.106-113, 2006.

[17] H. Hattori and A. Maki: "Stereo wightout depth search and metric calibration," Pro. CVPR, vol.I, pp.177-184, 2000.

[18] M. Kass, A. Witkin and D. Terzopoulos: "Snakes: Active Contour Models," International Journal Computer Vision, vol.1, no.4, pp.321-331, 1988.

[19] 中山啓満, 窪田進, 谷口恭弘, 小野口一則 : “逆投影画像上での候補追跡 処理による白線検出”, 電子情報通信学会研究会, PRMU 101(302), pp.15-22, 2001.

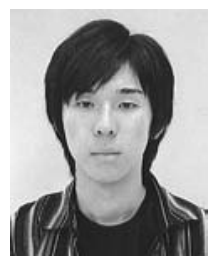

葛西達哉（Tatsuya Kasai）

2009 年弘前大学理工学部電子情報システム工学科 卒業. 同年弘前大学大学院理工学研究科電子情報シ ステム工学専攻博士前期課程入学, 現在に至る。

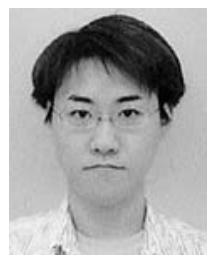

佐藤正明（Masaaki Sato）

2007 年弘前大学理工学部電子情報システム工学科 卒業. 2009 年弘前大学大学院理工学研究科博士前 期課程修了。同年日立ソフトウェアエンジニアリン グ株式会社入社，現在に至る.

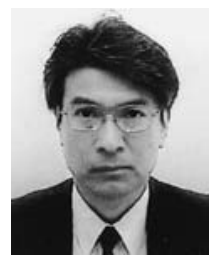

小野ロ一則（Kazunori Onoguchi）

1982 年東北大学工学部通信工学科卒業, 1984 年東 北大学大学院工学研究科修士課程修了. 同年 (株) 東芝入社。総合研究所, 研究開発センターにおい てコンピュータビジョン, 移動ロボット, ITS 画像 処理の研究に従事. 2004 年弘前大学理工学部教授, 2007 年より弘前大学大学院理工学研究科教授, 現 在に至る. 博士 (情報科学). IEEE, 電子情報通信学会, 情報処理学 会, 計測自動制御学会各会員.

（日本ロボット学会正会員）

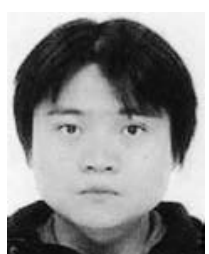

岩瀬耕二（Kouji Iwase）

2003 年 3 月大阪大学工学部応用理工学科卒業, 2005 年同大学大学院修士課程修了. 同年マツダ株式会社 に入社. 現在, 走行環境認識技術に関する研究に従 事. 電子情報通信学会会員 